\title{
Financial Performance Analysis of Selected Iron and Steel Companies in India
}

\author{
K.R. Sivabagyam, Harshitha.B, Gowthami. D, Jayakrithika.R, Nivethitha. G
}

\begin{abstract}
Financial Analysis is a process of identifying the financial strength and weakness of the firm by establishing relationships between the items, the balance sheet and profit and loss account. Financial analysis helps to assess the financial position and profitability of a concern. In this study to assess the selected firm's financial status, ratio analysis has applied covering profitability, solvency and turnover ratios. This study evaluates and compares the performance of 10 steel companies (VISA, TATA, JSW, SAIL, ESSAR, JINDAL, UTTAM GALVA, SUNFLAG, FACOR, and NARAYANI STEELS). The period of the study is 5 years starting from 2014-15 to 2018-19. The research study has analyzed the performance of selected steel companies. The methodology of the present study includes sampling, data collection and data analysis tools used for the study. The present research study is based on purely secondary data. The data for this analysis is taken from Moneycontrol.com and other related information is taken from concerned steel company websites, books, and journals. In this research study, different statistical tools have been used like mean, Standard deviation, Coefficient of variation and Analysis of variance (ANOVA) applied for processing the data to give reliable conclusion. Comparing all the profitability ratios, it is inferred that Out of the 3 ratios, it is inferred that Tata steels have performed better in gross profit and net profit ratio, and ESSAR steels performed better in operating profit ratio and the other selected companies in the study have to improve its level better in the coming years to reach next level. Comparing short term liquidity ratios, it is inferred that out of 2 ratios, Sunflag and Narayani steels have performed better in current and quick ratio, and other selected companies in this study have to improve its level. Comparing the efficiency ratios, it is inferred that out of 3 ratios Narayani steels and Tata steels performed better and other selected companies have to improve its level.
\end{abstract}

\section{INTRODUCTION}

Iron and steel sector is the backbone of an economy. It is one of the primary vehicles of economic development of a country. Increase in the use of iron and steel leads to infrastructural development and rapid industrialization of the country. According to Pandit Jawaharlal Nehru," Steel is a symbol of strength of the economy and portent of the glory of India of the future.

Iron and steel are basic requirements for all types of construction and manufacturing activities. It is used as a basic material of manufacturing all types of machinery, electrical and metal products, transport equipment,

Revised Manuscript Received on September 14, 2019.

Dr. K.R. Sivabagyam, M.Com. M.Phil., Ph.D., SET, MBA, PGDCA, Assistant Professor, Department of Commerce, Sri Krishna Arts and Science College, Bharathiar University, Coimbatore, Tamil Nadu, India

Harshitha.B, M. Com Students, Sri Krishna Arts and Science College, Bharathiar University, Coimbatore, Tamil Nadu, India.

Gowthami. D, M. Com Students, Sri Krishna Arts and Science College, Bharathiar University, Coimbatore, Tamil Nadu, India.

Jayakrithika.R, M. Com Students, Sri Krishna Arts and Science College, Bharathiar University, Coimbatore, Tamil Nadu, India.

Nivethitha. G, M. Com Students, Sri Krishna Arts and Science College, Bharathiar University, Coimbatore, Tamil Nadu, India. agricultural equipment, capital goods, house building etc. So, all industries have to depend on iron and steel.

\section{HISTORY OF STEEL INDUSTRY}

The first successful attempt was made in 1875in setting up an iron and steel works at Barakar by Bengal Iron and Steel Company. This was taken over by Bengal Iron Company in 1889. This was the first attempt to produce pig iron in India through modern methods. But the iron and steel industry in India had a real beginning in the year 1907 after the establishment of Tata Iron and Steel Company (TISCO) at Sakchi in Bihar. It was the dream of late Jamshetji Tata, the father of Indian Steel industry, whose career was a true example of industrial romance. His dream came into reality in the form establishment of TISCO, the first large scale industrial unit in producing iron and steel by using latest scientific methods in India.

Following are the list of selected Iron and steel companies in this study.

\begin{tabular}{|c|l|c|c|}
\hline S.N0 & $\begin{array}{c}\text { NAME OF THE STEEL } \\
\text { INDUSTRY }\end{array}$ & $\begin{array}{c}\text { YEAR OF } \\
\text { ESTABLISHMENT }\end{array}$ & HEADQUARTER'S \\
\hline 1 & VISA steel company & 1996 & Kolkata, India. \\
\hline 2 & TATA stel company & 1907 & Mumbai, India. \\
\hline 3 & JSW steel company & 1982 & Mumbai, India. \\
\hline 4 & SAIL steel compary & 1954 & New Delhi, India. \\
\hline 5 & ESSAR steel company & 1969 & Mumbai, Maharashtra, India. \\
\hline 6 & JINDAL steel company & 1952 & New Delhi, India. \\
\hline 7 & UTTAM GALVA steel company & 1985 & Mumbai, India. \\
\hline 8 & SUNFLAG steel company & 1984 & Maharashrra, India. \\
\hline 9 & FACOR steel company & 1956 & Nagpur, Maharashtra, India. \\
\hline 10 & NARAYANI steel company & 1985 & Andhra Pradesh, India. \\
\hline
\end{tabular}

\section{PROSPECTS OF INDIAN IRON AND STEEL INDUSTRY}

Abundance of raw material and manpower resources, unexplored rural market,

Market potentiality in other sectors, potentiality in global market, structural/infrastructural advantage.

\section{PROBLEMS OF INDIAN IRON AND STEEL INDSUTRY}

Though there has been a considerable progress in iron and steel industry in India particularly after labialization, still it has been facing some problems. Shortage of raw material base, Shortage of power, Transportation problem, Increase in input cost and problem of administered price, Underutilization of capacity, inefficient management, High cost of

Published By:

Blue Eyes Intelligence Engineering

\& Sciences Publication 
capital, low labour productivity, Lack of technological development.

\section{STATEMENT OF THE PROBLEM}

Financial analysis in terms of profitability, solvency and efficiency is considered as the backbone of any sector.. The study of the financial performance is important to know the operating and financial efficiency of the business enterprise. Survival of the business in the present competitive world depends on the quality production, technological development and financial analysis in the business. Therefore, the present study attempts to study the financial performance of the selected Steel in India.

\section{OBJECTIVES OF THE STUDY}

The main objectives of the study are to analyze the profitability, short term solvency and efficiency ratios of selected steel companies in India.

In tune with, the following are the important objectives of the study:

$>$ To analyze the financial performance of the company with the help of its profitability, short term solvency and efficiency ratios.

$>\quad$ To find out the variance among the mean values of ratios in steel companies.

$>\quad$ To ascertain the plus and minus points of the company.

To suggest suitable measure to improve he financial health of the companies.

\section{REVIEW OF LITERATURE}

Amalendu Bhunia13, in March, 2007, writes an article on ?Liquidity Management of Public Sector Iron and Steel Enterprises in India?, Vidyasagar University Journal of Commerce Vol. 12, March 2007. The paper makes an assessment of management of working capital, examines the adequacy or otherwise of the working capital, observes the liquidity position and areas of weakness and gives suggestions for removal of the weaknesses of the public sector Iron and Steel enterprises in India. In this study the researcher focused on only public sector companies who are engaged in steel production and study also focused only on its liquidity management where other factors which affect the efficiency of the company is not considered by the author and find the gap for the further study in the steel industry and the financial efficiency study.

Lal Manohar26, in 1990, in his doctoral research on ?A Comparative Study of Financial Health of SAIL and TISCO?, submitted to the Kurukshetra University, has undertaken a comparative study of financial health of SAIL and TISCO. In this study the researcher focus on the financial health of the mentioned company SAIL and TISCO where he studied comparative financial statement of

Nageshwar Rao and R.P. Das27, in the year 2001 wrote an article on ?An Organizational Restructuring in Steel Authority of India Ltd.,? Indian Journal of Public Enterprise, IPER, Vol.16, No.30, where they have suggested that globalization calls for better management of multicultural environment, fast response to change and, subscription to SAIL and TISCO and made the comparative analysis.

globally accepted standards of quality, delivery and price, SAIL has to change the mindset of their employees. It should withdraw from those business activities that do not add value to their core activity of making steel.

\section{RESEARCH METHODOLOGY}

\section{A. Data collection:}

The study is an empirical and analytical study based on the secondary data which are collected from the published financial statements viz., annual reports of the selected steel companies in India.

\section{B. Tools Applied:}

Financial Tools: Ratio Analysis

Statistical tools: Mean, Standard Deviation and Coefficient of variation and ANOVA

Following are the tools applied in this study

1. Gross profit ratio

2. Net profit ratio

3. Operating profit ratio

4. Current ratio

5. Quick ratio

6. Stock turnover ratio

7. Debtors turnover ratio

8. Fixed assets turnover ratio

ANOVA Technique is used to compare three or more no of groups on the basis of their mean values. In this study also 10 companies? performance is to be compared on the basis of their different mean ratios. The ANOVA test tells whether there are overall difference between the groups, but it does not tell which specific groups differed.

\section{RESULTS, FINDINGS AND DISCUSSION}

\begin{tabular}{|c|c|c|c|c|c|c|c|c|c|}
\hline \multicolumn{10}{|c|}{$\begin{array}{c}\text { Table } \mathrm{N}_{0.1} \\
\text { GROSS PROFIT RATIO }\end{array}$} \\
\hline \multicolumn{2}{|c|}{$\begin{array}{l}\text { COMPANY } \\
\text { NAME }\end{array}$} & 2014-15 & $2015-16$ & \begin{tabular}{|l|l|}
$2016-17$ &
\end{tabular} & $2017-18$ & 2018-19 & AVERAGE & SD & $\mathrm{COV}$ \\
\hline \multicolumn{2}{|l|}{ VISA } & -6.44 & .6 .57 & -9.59 & .8 .76 & -11.21 & -8.514 & 2.035 & 23.9 \\
\hline \multicolumn{2}{|l|}{ TATA } & 19.17 & 13.81 & 17.36 & 20.21 & 23.73 & 18.856 & 3.653 & 19.38 \\
\hline \multicolumn{2}{|l|}{ JSW } & 13.2 & 9.59 & 16.29 & 16.44 & 19.55 & 15.014 & 3.773 & 25.13 \\
\hline \multicolumn{2}{|l|}{ SAIL } & 6.3 & .13 .57 & .5 .94 & 2.69 & 9.48 & -0.208 & 9.434 & 4536 \\
\hline \multicolumn{2}{|l|}{ ESSAR } & 24.52 & 19.28 & 17.82 & 14.81 & 14.37 & 18.16 & 4.105 & 22.6 \\
\hline \multicolumn{2}{|c|}{ JINDAL } & 14.33 & 2.3 & 6.19 & 12.09 & 13.38 & 9.658 & 5.19 & 53.74 \\
\hline \multicolumn{2}{|c|}{ UTTAM } & 4.05 & -4.83 & -1.93 & .11 .89 & .53 .91 & .13 .702 & 23.2 & 169.3 \\
\hline \multicolumn{2}{|c|}{ SUNFLAG } & 6.72 & 8.42 & 7.4 & 9.77 & 8.96 & 8.254 & 1.215 & 14.72 \\
\hline \multicolumn{2}{|c|}{ FACOR } & -0.49 & -8.12 & -30.86 & -80.87 & .702 .29 & -164.526 & 302.3 & 183.7 \\
\hline \multicolumn{2}{|c|}{ NARAYANI } & 1.6 & 2.36 & 2.29 & 2.4 & 2.14 & 2.158 & 0.327 & 15.17 \\
\hline \multicolumn{10}{|c|}{$\begin{array}{l}\text { Null Hypothesis: All the comparies under study have on an average same level of Gross Profit } \\
\text { Ratio. }\end{array}$} \\
\hline \multicolumn{10}{|c|}{$\begin{array}{l}\text { Alternate Hypothesis: All the companies under study do not have on anaverage same level of } \\
\text { Gross Profit Ratio. }\end{array}$} \\
\hline \multicolumn{10}{|c|}{ ANOVA } \\
\hline \multirow{4}{*}{$\begin{array}{l}\text { Gross } \\
\text { Profit } \\
\text { Ratio }\end{array}$} & & & Sum & of Squares & $\mathrm{DF}$ & Mean & Square & $\mathrm{F}$ & SIG \\
\hline & & een Groups & & 5250.3 & 9 & 150 & 27.81 & \multirow{3}{*}{1.63} & \multirow{3}{*}{2.13} \\
\hline & & in Groups & & 8242.5 & 40 & & 6.062 & & \\
\hline & & Total & & 3676.7 & 49 & & & & \\
\hline
\end{tabular}

Published By: 
From the above table no.1, it is understood that the Gross Profit ratio for the selected steel companies ranges minimum of -702.29 for FACOR during the year 2018-19 and maximum of 24.52 for ESSAR during the year 2014-15. The minimum average ratio of -164.526 for FACOR and maximum average ratio for TATA. The minimum ratio indicates that the company earned less Gross Profit comparative to other companies. The maximum ratio indicates that the company would have earned more profit in the selected steel companies.

The minimum average ratio of -164.526 Per cent for FACOR indicates that the company has the lowest average performance compared to other selected steel companies. The TATA has the highest average Gross Profit ratio indicting good performance But the consistency is more only for the VISA because of the lowest Co-efficient of Variation 23.9 percent. The SAIL has got more volatility as far as performance is concerned, because of the highest Co efficient of Variation of 4536 percent.

From the ANOVA table it is inferred that the calculated value (1.63) of $F$ is less than the table value (2.13) at (0.05) level, accept the null hypothesis, i.e., there is no significant difference between gross profit of the selected steel Companies.

Table No.2

NET PROFIT RATIO

\begin{tabular}{|c|c|c|c|c|c|c|c|c|}
\hline $\begin{array}{l}\text { COMPANY } \\
\text { NAME }\end{array}$ & 2014-15 & $2015-16$ & $\begin{array}{l}2016- \\
17\end{array}$ & 2017-18 & 2018-19 & AVERAGE & SD & $\mathrm{COV}$ \\
\hline VISA & -26.18 & -115.49 & -10.21 & -9.08 & -11.41 & -34.474 & 45.82 & 132.9 \\
\hline TATA & 15.41 & 12.82 & 7.17 & 6.99 & 14.91 & 11.46 & 4.115 & 35.91 \\
\hline JSW & 4.7 & -9.61 & 6.84 & 7.11 & 10.76 & 3.96 & 7.892 & 199.3 \\
\hline SAII & 4.57 & -10.29 & -6.37 & -0.83 & 3.25 & -1.934 & 6.322 & 326.9 \\
\hline ESSAR & 9.67 & 8.54 & 5.35 & 3.96 & 1.56 & 5.816 & 3.318 & 57.06 \\
\hline JINDAL & -2.32 & -11.17 & -7.12 & -2.11 & -0.94 & -4.732 & 4.308 & 91.03 \\
\hline $\begin{array}{l}\text { UTTAM } \\
\text { GALVA }\end{array}$ & 0.44 & -15.21 & -10.24 & -34.58 & -382.11 & -88.34 & 164.7 & 186.5 \\
\hline SUNFLAG & 1.38 & 3.45 & 4.29 & 6.2 & 4.96 & 4.056 & 1.803 & 44.44 \\
\hline FACOR & -2.75 & -10.07 & -42.54 & -42.25 & -949.72 & -209.466 & 414.2 & 197.7 \\
\hline NARAYANI & 0.23 & 0.24 & 0.27 & 0.26 & 0.29 & 0.258 & 0.024 & 9.254 \\
\hline \multicolumn{9}{|c|}{$\begin{array}{l}\text { Null Hypothesis: All the comparies under study have on an average same level of Net Profit } \\
\text { Ratio. }\end{array}$} \\
\hline \multicolumn{9}{|c|}{$\begin{array}{l}\text { Alternate Hypothesis: All the companies under study do not have on an average same level of } \\
\text { Net Profit Ratio. }\end{array}$} \\
\hline \multicolumn{9}{|c|}{$\begin{array}{ll} & \text { ANOVA } \\
\end{array}$} \\
\hline \multirow{4}{*}{$\begin{array}{c}\text { Net Profit } \\
\text { Ratio }\end{array}$} & & & Sum of & quares & $\mathrm{DF}$ & Iean Square & $\mathrm{F}$ & SIG \\
\hline & Between $\mathrm{C}$ & roups & 2163 & & 9 & 24039 & \multirow{3}{*}{1.20} & \multirow{3}{*}{2.13} \\
\hline & Within $\mathrm{Gr}$ & & 8038 & & 40 & 20095.45 & & \\
\hline & Total & & 1020 & & 49 & & & \\
\hline
\end{tabular}

Source: Constructed ratios from moneycontrol.com

From the above Table No. 2 it is understood that the Net Profit ratio for the selected steel companies ranges minimum of -949.72 for FACOR during the year 2018-19 and maximum of 15.41 for TATA during the year 2014-15. The minimum average ratio of -209.466 for FACOR and maximum average ratio of 11.46 for TATA. The minimum ratio indicates that the company earned less Net Profit comparative to other companies. The maximum ratio indicates that the company would have earned more net profit in the selected steel companies.

The minimum average ratio of -209.466 Per cent for FACOR indicates that the company has the lowest average performance compared to other selected companies. The TATA Steel has the highest average Net Profit ratio indicates good performance. But the consistency is more for the Narayani steels because of the lowest Co-efficient of Variation 9.254 percent. The SAIL has got more volatility as far as performance is concerned, because of the highest Co efficient of Variation of 326.9 per cent.

From the ANOVA table it is inferred that since Calculated $F$ value (1.20) is less than the table value at $5 \%$ level ( 2.13) accept Null hypothesis. i.e., there is no significant difference between the mean values of Gross profit ratio.

Table $\mathrm{N}_{0.3} 3$

OPERATING PROFIT RATIO

\begin{tabular}{|c|c|c|c|c|c|c|c|c|}
\hline $\begin{array}{l}\text { COMPANY } \\
\text { NAME }\end{array}$ & $2014-15$ & $2015-16$ & $2016-17$ & 2017-18 & 2018-1. & AVERAGE & SD & $\mathrm{COV}$ \\
\hline VISA & -0.22 & 0.58 & 1.16 & 0.02 & -1.8 & -0.052 & 0.996 & 1915 \\
\hline TATA & 23.95 & 18.87 & 24.74 & 26.46 & 29.12 & 24.628 & 3.381 & 13.73 \\
\hline \begin{tabular}{|l} 
JSW \\
\end{tabular} & 19.24 & 17.35 & 22.07 & 21.14 & 23.98 & 20.756 & 2.288 & 11.02 \\
\hline SAIL & 10.18 & .7 .42 & 0.08 & 8.02 & 14.53 & 5.078 & 7.813 & 153.9 \\
\hline ESSAR & 31.96 & 24.23 & 24.75 & 21.93 & 21.44 & 24.862 & 3.771 & 15.17 \\
\hline JINDAL & 27.67 & 19.22 & 20.95 & 23.28 & 21.7 & 22.564 & 2.868 & 12.71 \\
\hline $\begin{array}{l}\text { UTTAM } \\
\text { GALVA }\end{array}$ & 7.27 & -0.74 & 4.63 & -1.76 & -8.48 & 0.184 & 5.471 & \begin{tabular}{|l|l|}
2974 \\
\end{tabular} \\
\hline SLNFLAG & 9.63 & 11.53 & 9.58 & 11.41 & 10.66 & 10.562 & 0.837 & 7.92 \\
\hline FACOR & 1.23 & .5 .91 & .22 .71 & -65.01 & -423.3 & -103.144 & 161.7 & 156.8 \\
\hline NARAYANI & 1.7 & 2.47 & 2.36 & 2.48 & 2.26 & 2.254 & 0.288 & 12.8 \\
\hline \multicolumn{9}{|c|}{$\begin{array}{l}\text { Null Hypothesis: All the comparies under study have on an average same level of Operating } \\
\text { Profit Ratio. }\end{array}$} \\
\hline \multicolumn{9}{|c|}{$\begin{array}{l}\text { Alternate Hypothesis: All the companies under study do not have on anaverage same level of } \\
\text { Operating Profit Ratio. }\end{array}$} \\
\hline \multicolumn{9}{|c|}{ ANOVA } \\
\hline \multirow{4}{*}{$\begin{array}{l}\text { Operating } \\
\text { ProfitRatio }\end{array}$} & & & Sum of & Squares & $\mathrm{DF}$ & Mean Square & $\mathrm{F}$ & SIG \\
\hline & Betwee & Groups & 6469 & & 9 & 7188.795 & \multirow{3}{*}{2.19} & \multirow{3}{*}{2.1} \\
\hline & Within & roups & 1314 & & 40 & 3286.105 & & \\
\hline & To & & 1961 & & 49 & & & \\
\hline
\end{tabular}

Source: Constructed ratios from moneycontrol,com

From the above table no. 3 it is understood that the Operating Profit ratio for the selected steel companies ranges minimum of -423.32 for FACOR during the year 2018-19 and maximum of 31.96 for ESSAR during the year 2014-15. The minimum average ratio of -103.144 for FACOR and maximum average ratio of 24.862 for ESSAR The minimum ratio indicates that the company earned less Operating Profit comparative to other companies. The maximum ratio indicates that the company would have earned more profit in the selected steel companies.

The minimum operating profit ratio of - 103.144 Per cent for FACOR steel indicates that the company has the lowest average performance compared to other selected companies. The ESSAR has the highest average Operating Profit ratio indicates good performance But the consistency is more only for the Sunflag because of the lowest Co-efficient of Variation 7.92 percent. The UTTAM GALVA has got more volatility as far as operating profit is concerned, because of the highest Co -efficient of Variation of 2974 percent.

From the ANOVA table it is inferred that since the calculated value $F$ value (2.19) more than the level of significance 0.05 , accept the alternate hypothesis. i.e., there is a significant difference between the selected Steel

Published By:

Blue Eyes Intelligence Engineering \& Sciences Publication 
Companies in the Operating profit ratio. Hence to find out which company differs significant from other companies, Post Hoc tests can be applied.

Table $\mathrm{N}_{0.4}$

CURRENT RATIO

\begin{tabular}{|c|c|c|c|c|c|c|c|c|}
\hline $\begin{array}{l}\text { COMPANY } \\
\text { NAME }\end{array}$ & $2014-15$ & $2015 \cdot 16$ & 2016-17 & $2017 \cdot 18$ & $2018-19$ & AIERAGE & SD & $\mathrm{COV}$ \\
\hline VISA & 0.2 & 0.15 & 0.15 & 0.09 & 0.05 & 0.128 & 0.058 & 45.69 \\
\hline TATA & 0.62 & 0.52 & 0.55 & 0.64 & 0.55 & 0.576 & 0.051 & 8.903 \\
\hline JSIV & 1.02 & 0.67 & 0.79 & 0.98 & 0.81 & 0.854 & 0.144 & 16.9 \\
\hline SAII & 0.68 & 0.61 & 0.6 & 0.7 & 0.64 & 0.646 & 0.043 & 6.712 \\
\hline ESSAR & 1.23 & 0.85 & 0.77 & 0.67 & 0.71 & 0.846 & 0.225 & 26.61 \\
\hline JINDAL & 0.74 & 0.36 & 0.32 & 0.34 & 0.36 & 0.424 & 0.177 & 41.85 \\
\hline $\begin{array}{l}\text { UTTAM } \\
\text { GALVA }\end{array}$ & 0.7 & 0.57 & 0.42 & 0.26 & 0.79 & 0.548 & 0.213 & 38.87 \\
\hline SLNFLAG & 0.93 & 1.08 & 0.95 & 1.15 & 1.00 & 1.022 & 0.092 & 9.005 \\
\hline FACOR & 0.74 & 0.69 & 0.67 & 0.22 & 0.24 & 0.512 & 0.259 & 50.54 \\
\hline NARAYANI & 0.79 & 0.78 & 0.8 & 0.77 & 0.79 & 0.786 & 0.011 & 1.451 \\
\hline \multicolumn{9}{|c|}{$\begin{array}{l}\text { Tull Hypothesis: All the comparies under study have on an average same level of Current } \\
\text { Ratio. }\end{array}$} \\
\hline \multicolumn{9}{|c|}{$\begin{array}{l}\text { Alternate Hypothesis: All the companies under study do not have on anaverage samelevel of } \\
\text { Current Ratio. }\end{array}$} \\
\hline \multicolumn{9}{|c|}{ ANOVA } \\
\hline \multirow{4}{*}{$\begin{array}{c}\text { Current } \\
\text { Ratio }\end{array}$} & & & Sum of & Squares & $\mathrm{DF}$ & Mean Square & $F$ & SIG \\
\hline & Between & Groups & 2.964 & 4578 & 9 & 0.329398 & \multirow{3}{*}{14.21} & \multirow{3}{*}{2.13} \\
\hline & Within G & roups & 0.92 & & 40 & 0.023186 & & \\
\hline & Tota & & 3.892 & & 49 & & & \\
\hline
\end{tabular}

Source: Constructed ratios from moneycontrolcom

From the above table No.4 it is understood that the Current ratio for the selected steel companies ranges minimum of 0.05 for VISA during the year 2018-19 and maximum of 1.23 for ESSAR during the year 2014-15. The minimum average ratio of 0.128 for VISA and maximum average ratio of 1.022 for Sunflag. The minimum ratio indicates that the company had less current ratio indicates that the company would have taken initiative to get cash collection from debtors. The maximum ratio indicates that the company would have taken more initiative to get enough cash from debtors so that current ratio higher in the selected steel companies.

The minimum average ratio of 0.128 Per cent for VISA indicates that the company has the lowest average current ratio compared to other selected steel companies. The sunflag has the highest average current ratio indicates better than other companies but all selected companies have to improve its current ratio level in the coming years so that it can reach standard ratio of $2: 1$. But the consistency is more only for the Narayani Steels because of the lowest Coefficient of Variation 1.451 percent. The FACOR STEEL has got more volatility as far as current ratio is concerned, because of the highest Co -efficient of Variation of 50.54 percent.

From the ANOVA table it is inferred that since the calculated $\mathrm{F}$ value (14.21) is more than the level of significance 0.05 , accept the alternate hypothesis. i.e., there is significant difference between the selected steel Companies in current ratio. Hence to find out which company differs significant from other companies, Post Hoc tests can be applied.
Table $\mathrm{N}_{0.5}$

QUTCK RATIO

\begin{tabular}{|c|c|c|c|c|c|c|c|c|}
\hline \begin{tabular}{|l|} 
COMPAMY \\
NAME \\
\end{tabular} & 2014-15 & 2015.16 & $2016-17$ & 2017.18 & $2018-19$ & AVERAGE & SD & $\mathrm{COV}$ \\
\hline VISA & 0.26 & 0.24 & 0.19 & 0.1 & 0.04 & 0.166 & 994 & 5 \\
\hline TATA & 0.27 & 0.32 & 0.28 & 0.34 & 0.26 & 0.294 & 0.034 & 11.68 \\
\hline \begin{tabular}{|l|} 
JSW \\
\end{tabular} & 0.67 & 0.41 & 0.56 & 0.68 & 0.76 & 0.616 & 0.135 & 1.98 \\
\hline SAIL & 0.55 & 0.42 & 0.38 & 0.4 & 0.41 & 0.432 & 0.068 & 15.6 \\
\hline ESSAR & 0.83 & 0.9 & 0.45 & 0.41 & 0.62 & 0.642 & 0.22 & 34.2 \\
\hline \begin{tabular}{|l|} 
JINDAL \\
\end{tabular} & 1.22 & 0.59 & 0.54 & 0.45 & 0.35 & 0.63 & 0.342 & 54.3 \\
\hline $\begin{array}{l}\text { UTTAM } \\
\text { GALVA } \\
\end{array}$ & 0.52 & 0.52 & 0.58 & 0.32 & 0.34 & 0.456 & 0.118 & 25.8 \\
\hline SLNFLAG & 0.87 & 0.89 & 1.16 & 1.18 & 0.95 & 1.01 & 0.149 & 14.7 \\
\hline FACOR & 0.48 & 1.13 & 0.61 & 0.42 & 0.26 & 0.58 & 0.332 & 57.2 \\
\hline \begin{tabular}{|l|} 
NARAYAII \\
\end{tabular} & 1.62 & 1.97 & 1.73 & 2.24 & 1.91 & 1.894 & 0.239 & 12.6 \\
\hline \multicolumn{9}{|c|}{ Sull Hypothesis: All the comparies under study have on an average same level of Quick Ratio. } \\
\hline \multicolumn{9}{|c|}{$\begin{array}{l}\text { Alternate Hypothesis: All the companies under study do not have on anaverage samelevel of } \\
\text { Quick Ratio. }\end{array}$} \\
\hline \multicolumn{9}{|c|}{ ANOVA } \\
\hline \multirow{4}{*}{ Quick Ratio } & & & Sumo 0 & Squares & $\mathrm{DF}$ & Mean Square & $\mathrm{F}$ & SIG \\
\hline & Betwe & n Groups & & 2484 & 9 & 1.180538 & \multirow{3}{*}{$\begin{array}{c}29.3 \\
9\end{array}$} & \multirow{3}{*}{2.13} \\
\hline & Within & & & 0676 & 40 & 0.040169 & & \\
\hline & & & & & 49 & & & \\
\hline
\end{tabular}

Source: Constructed ratios from moneycontrol.com

From the above table No.5 it is understood that the Quick ratio for the selected steel companies ranges minimum of 0.04 for VISA during the year 2018-19 and maximum of 2.24 for Narayani steels during the year 2017-18. The minimum average ratio of 0.166 for VISA and maximum average ratio of 1.894 for Narayani steels. The minimum average ratio indicates that the company maintained less Quick ratio. The maximum ratio indicates that the company would have taken initiative to maintain high quick ratio in the selected steel companies.

The minimum ratio of 0.166 Per cent for VISA indicates that the company has below the ideal ratio of 1:1 compared to other selected steel companies. The Narayani steels has the highest average current ratio indicates that it maintained the ideal ratio of $1: 1$. But the consistency is more for the TATA STEELS because of the lowest Co-efficient of Variation 11.68 percent. The FACOR has got more volatility as far as quick ratio is concerned, because of the highest Co -efficient of Variation of 57.27 percent.

From the ANOVA table it is inferred that since the calculated $F$ value (29.39) is more than the level of significance 0.05 , accept the alternate hypothesis. i.e., there is significant difference between the selected steel Companies in Quick ratio. Hence to find out which company differs significant from other companies, Post Hoc tests can be applied. 
Table $\mathrm{N}_{0.6}$

STOCK TURNOVER RATIO

\begin{tabular}{|c|c|c|c|c|c|c|c|c|}
\hline $\begin{array}{l}\text { COMPANY } \\
\text { NAME }\end{array}$ & $\begin{array}{l}2014- \\
15\end{array}$ & 2015-16 & 2016-17 & $2017-18$ & 2018-19 & AVERAGE & SD & $\mathrm{COV}$ \\
\hline VISA & 8.75 & 4.35 & 8.04 & 13.43 & 13.88 & 9.69 & 3.99 & 41.17 \\
\hline TATA & 5.79 & 6.03 & 5.2 & 5.49 & 6.27 & 5.756 & 0.424 & 7.372 \\
\hline JSW & 5.87 & 6.06 & 6.14 & 6.57 & 7.24 & 6.376 & 0.547 & 8.575 \\
\hline SAIL & 2.88 & 2.99 & 3.17 & 3.47 & 3.44 & 3.19 & 0.263 & 8.255 \\
\hline ESSAR & 6.54 & 4.18 & 3.5 & 8.94 & 8.69 & 6.37 & 2.502 & 39.29 \\
\hline JINDAL & 3.94 & 6.02 & 8.21 & 5.65 & 7.12 & 6.188 & 1.607 & 25.97 \\
\hline $\begin{array}{l}\text { UTTAM } \\
\text { GALVA }\end{array}$ & 5.82 & 8.02 & 5.38 & 6.66 & 1.43 & 5.462 & 2.468 & 45.19 \\
\hline SUNFLAG & 4.97 & 5.92 & 4.38 & 4.92 & 4.04 & 4.846 & 0.714 & 4.74 \\
\hline FACOR & 4.01 & 7.92 & 1.45 & 3.16 & 0.22 & 3.352 & 2.948 & 87.95 \\
\hline NARAYANI & 11.91 & 13.55 & 13.64 & 39.57 & 42.02 & 24.138 & 15.25 & 63.16 \\
\hline \multicolumn{9}{|c|}{$\begin{array}{l}\text { Null Hypothesis: All the comparies under study have on an average same level of Stock } \\
\text { Tumover Ratio. }\end{array}$} \\
\hline \multicolumn{9}{|c|}{$\begin{array}{l}\text { Alternate Hypothesis: All the companies under study do not have on anaverage same level of } \\
\text { Stock Tumover Ratio. }\end{array}$} \\
\hline \multicolumn{9}{|c|}{ ANOVA } \\
\hline \multirow{4}{*}{$\begin{array}{c}\text { Stock } \\
\text { Turnover } \\
\text { Ratio }\end{array}$} & & & Sum 0 & Squares & $\mathrm{DF}$ & Mean square & $\mathrm{F}$ & SIG \\
\hline & Between & Groups & & 9.44 & 9 & 186.6044 & \multirow{3}{*}{6.83} & \multirow{3}{*}{2.13} \\
\hline & Within & Groups & & & 40 & 27.30404 & & \\
\hline & & & & & 49 & & & \\
\hline
\end{tabular}

Source: Constructed ratios from moneycontrol.com

From the above table No. 6 it is understood that the stock turnover ratio for the selected steel companies ranges minimum of 0.22 for FACOR during the year 2018-19 and maximum of 42.02 for Narayani steels during the year 201819. The minimum average ratio of 3.19 for SAIL and maximum average ratio of 24.138 for Narayani steels. The minimum ratio indicates that the company earned less stock turnover ratio comparative to the other companies. The maximum ratio indicates that the company would have managed the stock velocity better than other selected steel companies.

The minimum average ratio of 3.19 Per cent for SAIL indicates that the company is having low velocity of conversion of stock into sales compared to other selected steel companies. The Narayani steels has the highest average stock turnover ratio indicates efficient management of inventory because more frequently the stocks are sold, the lesser the amount of money is required to finance the inventory, but the consistency is more for TATA Steels because of the lowest Co-efficient of Variation 7.372 percent. The FACOR has got more volatility as far as stock turnover is concerned, because of the highest Co -efficient of Variation of 87.95 percent.

From the ANOVA table it is inferred that since the calculated $F$ value (6.83) is more than the level of significance 0.05 , accept the alternate hypothesis. i.e., there is significant difference between the selected steel Companies in stock turnover ratio. Hence to find out which company differs significant from other companies, Post Hoc tests can be applied.
Table N0.7

DEBTORS TURNOVER RATIO

\begin{tabular}{|c|c|c|c|c|c|c|c|c|}
\hline $\begin{array}{l}\text { COMPANY } \\
\text { NAME }\end{array}$ & $\begin{array}{c}2014- \\
15\end{array}$ & $2015 \cdot 16$ & 2016-17 & 2017-18 & 2018-19 & AVERAGE & SD & $\mathrm{COV}$ \\
\hline VISA & 19.02 & 4.94 & 9.65 & 15.42 & 28.39 & 15.484 & 9.004 & 58.15 \\
\hline TATA & 66.21 & 67.97 & 36.67 & 30.71 & 43.6 & 49.032 & 17.12 & 34.91 \\
\hline JSW & 21.71 & 16.18 & 16.19 & 15.04 & 13.42 & 16.508 & 3.121 & 18.91 \\
\hline SAII & 10.54 & 12.33 & 14.66 & 16.95 & 16.01 & 14.098 & 2.641 & 18.73 \\
\hline ESSAR & 14.1 & 12.2 & 14.88 & 23.73 & 30.35 & 19.052 & 7.72 & 40.52 \\
\hline JINDAL & 9.63 & 11.8 & 17.01 & 21.45 & 32.65 & 18.508 & 9.148 & 49.42 \\
\hline $\begin{array}{l}\text { UTTAM } \\
\text { GALVA }\end{array}$ & 6.34 & 5.12 & 3.27 & 4.19 & 18.15 & 7.414 & 6.108 & 82.39 \\
\hline SUNFLAG & 8.87 & 8.33 & 6.6 & 7.53 & 7.59 & 7.784 & 0.863 & 11.09 \\
\hline FACOR & 11.99 & 13.76 & 5.65 & 3.59 & 0.42 & 7.082 & 5.642 & 79.66 \\
\hline NARAYANI & 6.8 & 5.43 & 6.52 & 4.96 & 3.83 & 5.508 & 1.206 & 21.89 \\
\hline \multicolumn{9}{|c|}{$\begin{array}{l}\text { Null Hypothesis: All the comparies under study have on an average same level of Debtors } \\
\text { Tumover Ratio. }\end{array}$} \\
\hline \multicolumn{9}{|c|}{$\begin{array}{l}\text { Alternate Hypothesis: All the comparies under study do not have on an average same level of } \\
\text { Debtors Tumover Ratio. }\end{array}$} \\
\hline \multicolumn{9}{|c|}{ ANOVA } \\
\hline \multirow{4}{*}{$\begin{array}{c}\text { Debtors } \\
\text { Turnover } \\
\text { Ratio }\end{array}$} & & & Sum of & Squares & $\mathrm{DF}$ & Mean Square & $\mathrm{F}$ & SIG \\
\hline & Between & Groups & 7188 & & 9 & 798.7319 & \multirow{3}{*}{13.15} & \multirow{3}{*}{2.13} \\
\hline & Within $\mathrm{G}$ & Jroups & 2428 & & 40 & 60.72118 & & \\
\hline & Tota & & 9617 & & 49 & & & \\
\hline
\end{tabular}

From the above table No. 7 it is understood that the debtors turnover ratio for the selected steel companies ranges minimum of 0.42 for FACOR during the year 201819 and maximum of 67.97 for TATA Steels during the year 2015-16. The minimum average ratio of 5.508 for Narayani steels and maximum average ratio of 49.032 for TATA steels. The minimum ratio indicates that the company has poor or less effective management of sales or debtors and liquid of debtors comparative to other companies. The high ratio indicates that the company would have managed the debtors, sales and liquid debtors better in the selected steel companies.

The minimum ratio of 5.508 Per cent for Narayani steels indicates that the company has the lowest average indicates that the company managed its sales badly. The TATA steels has the highest average debtors turnover ratio indicates effective management of sales. But the consistency is more for the Sunflag steels because of the lowest Co-efficient of Variation 11.09 percent. The UTTAM GALVA has got more volatility as far as debtors turnover is concerned, because of the highest Co -efficient of Variation of 82.39 percent.

From the ANOVA table it is inferred that since significant value $(0.000)$ is less than the level of significance 0.05 , reject the Null hypothesis and accept the alternate hypothesis. i.e., there is significant difference between the Ceramic Companies in gross profit ratio. Hence to find out which company differs significant from other companies, Post Hoc tests is applied.

From the ANOVA table it is inferred that since the calculated $\mathrm{F}$ value (13.15) is more than the level of significance 0.05 , accept the alternate hypothesis. i.e., there is significant difference between the selected steel 
Companies in debtors turnover ratio. Hence to find out which company differs significant from other companies, Post Hoc tests can be applied.

\section{Table No. 8}

FIXED ASSET TURNOVER RATIO

\begin{tabular}{|c|c|c|c|c|c|c|c|c|}
\hline $\begin{array}{l}\text { COMPANY } \\
\text { NAME }\end{array}$ & \begin{tabular}{c|c}
$2014-$ \\
15
\end{tabular} & $2015-16$ & $2016-17$ & 2017-18 & 2018-19 & AVERAGE & SD & $\mathrm{COV}$ \\
\hline VISA & 0.3 & 0.16 & 0.42 & 0.48 & 0.46 & 0.364 & 0.134 & 36.74 \\
\hline TATA & 1 & 0.88 & 0.6 & 0.72 & 0.82 & 0.804 & 0.153 & 18.98 \\
\hline JSW & 0.86 & 0.74 & 0.93 & 1.12 & 1.26 & 0.982 & 0.208 & 21.15 \\
\hline SAII & 0.72 & 0.51 & 0.54 & 0.61 & 0.67 & 0.61 & 0.087 & 14.34 \\
\hline ESSAR & 1.63 & 0.94 & 0.84 & 0.73 & 0.76 & 0.98 & 0.372 & 38 \\
\hline JINDAL & 0.39 & 0.28 & 0.3 & 0.33 & 0.6 & 0.38 & 0.13 & 34.16 \\
\hline $\begin{array}{l}\text { UTTAM } \\
\text { GALVA }\end{array}$ & 1.14 & 0.94 & 0.59 & 0.35 & 0.11 & 0.626 & 0.42 & 67.14 \\
\hline SUNFLAG & 1.34 & 1.25 & 1.16 & 1.56 & 3.12 & 1.686 & 0.815 & 48.36 \\
\hline FACOR & 3.41 & 2.68 & 0.69 & 0.64 & 0.02 & 1.488 & 1.468 & 98.69 \\
\hline NARAYANI & 42.04 & 32.92 & 44.64 & 34.12 & 32.73 & 37.29 & 5.624 & 15.08 \\
\hline \multicolumn{9}{|c|}{$\begin{array}{l}\text { Null Hypothesis: All the comparies under study have on an average same level of Fixed Asset } \\
\text { Tumover Ratio. }\end{array}$} \\
\hline \multicolumn{9}{|c|}{$\begin{array}{l}\text { Alternate Hypothesis: All the companies under study do not have on anaverage same level of } \\
\text { Fixed Asset Tumover Ratio. }\end{array}$} \\
\hline \multicolumn{9}{|c|}{ ANOVA } \\
\hline \multirow{4}{*}{$\begin{array}{c}\text { Fixed Asset } \\
\text { Turnover } \\
\text { Ratio }\end{array}$} & & & Sum 0 & f Squares & DF & Mean Square & $\mathrm{F}$ & SIG \\
\hline & Betwee & $n$ Groups & & 4.092 & 9 & 663.788 & \multirow{3}{*}{$\begin{array}{c}190.3 \\
3\end{array}$} & \multirow{3}{*}{2.13} \\
\hline & Within & Groups & & .5052 & 40 & 3.487631 & & \\
\hline & & & & 3.597 & 49 & & & \\
\hline
\end{tabular}

From the above table No.8 it is understood that the fixed assets turnover ratio for the selected steel companies ranges minimum of 0.02 for FACOR during the year 2018-19 and maximum of 44.64 for Narayani during the year 2016-17. The minimum average ratio of 0.38 for JINDAL and maximum average ratio of 37.29 for Narayani steels. The minimum ratio indicates that the company has generated low sales by every rupee invested in fixed assets as compared to other selected steel companies. The maximum ratio indicates that the company has generated high sales in the selected steel companies.

The minimum fixed assets turnover ratio of 0.38 Per cent for JINDAL indicates that the company has generated low sales by every rupee invested in fixed assets as compared to other selected companies. The Narayani steels has the highest average Fixed assets turnover ratio indicates greater efficiency in the utilization of fixed assets. But the consistency is more for the SAIL because of the lowest Coefficient of Variation 14.34 percent. The FACOR has got more volatility as far as fixed assets turnover ratios are concerned, because of the highest Co -efficient of Variation of 98.69 percent.

From the ANOVA table it is inferred that since the calculated $F$ value (190.33) is more than the level of significance 0.05 , accept the alternate hypothesis. i.e., there is significant difference between the selected steel Companies in fixed assets turnover ratio. Hence to find out which company differs significant from other companies, Post Hoc tests can be applied

\section{FINDINGS}

$\checkmark \quad$ Comparing all the profitability ratios, it is inferred that Out of the 3 ratios, it is inferred that Tata steels have performed better in gross profit and net profit ratio, and ESAR steels performed better in operating profit ratio and the other selected companies in the study have to improve its level better in the coming years to reach next level.

$\checkmark \quad$ Comparing short term liquidity ratios, it is inferred that out of 2 ratios, Sunflag and Narayani steels have performed better in current and quick ratio, and other selected companies in this study have to improve its level.

$\checkmark \quad$ Comparing the efficiency ratios, it is inferred that out of 3 ratios Narayani steels and Tata steels performed better and other selected companies have to improve its level.

\section{SUGGESTION}

$\checkmark \quad$ VISA steels has to take some strategy to enhance its short term solvency.

$\checkmark \quad$ SAIL has to improve its quick ratio adjust to ideal ratio.

$\checkmark \quad$ JINDAL has to improve its sales with every rupee invested in fixed assets.

$\checkmark \quad$ FACOR has to improve its profitability ratios.

\section{CONCLUSION}

The present study has brought out the various facts about the financial performance of Indian steel industry. The suggestions made in this study of immense use for the companies to give appropriate decision for mitigating for future financial problems. In order to sustain in the global competitive world, the steel industry needs to monitor its financial performance continuously. Based on the analysis and its subsequent findings it is concluded that the Tata steels, Essar steels, Sunflag steels, Narayani steels performed well. The selected other sttel companies have to take initiate steps to improve its financial performance

\section{BIBLIOGRAPHY}

www.moneyconrol.com

https://www.equitymaster.com/research-it/sector-

info/steel/Steel-Sector-Analysis-Report.asp

https://shodhganga.inflibnet.ac.in/bitstream/10603/61997/ 10/10_chapter\%202.pdf.

\section{REFERENCES}

1. Srinivas Kolluru conducted a study on," a study of performance of Indian Steel companies during 19992003". The IUP Journal of applied economic, 2005.

2. ChiragGosalia conducted, A study on financial performance of Indian Non-Life Insurance Industry.

3. Amalendu Bhunia writes an article on -Liquidity Management of Public Sector Iron and Steel Enterprises in Indiall, Vidyasagar University Journal of Commerce Vol. 12, March 2007.

4. Lal Manohar, in 1990, submitted $\mathrm{PhD}$. on -A Comparative Study of Financial Health of SAIL and TISCOIl, to the Kurukshetra University.

5. Rao N., Das R.P., -Organizational Restructuring in Steel Authority of India Ltd.,\|l Indian Journal of Public Enterprise, IPER, Vol.16, No.30, June, 2001, pp.51-58. 